\title{
FLAXSEED AND FLAXSEED CAKE AS A SOURCE OF COMPOUNDS FOR FOOD INDUSTRY
}

\author{
C. Gutiérrez ${ }^{1,2}$, M. Rubilar ${ }^{1,2}$, C. Jara ${ }^{1}$, M. Verdugo ${ }^{1}$, J. Sineiro ${ }^{3}$, and C. Shene ${ }^{1,2}$ \\ ${ }^{1}$ Center of Food Biotechnology and Bioseparations, Scientific and Technological Bioresource \\ Nucleus (BIOREN-UFRO), Universidad de La Frontera, Francisco Salazar 01145, Temuco, \\ Chile. ${ }^{2}$ Centre for Agri-aquicultural Nutrition Genomics, Technology and Process Unit., \\ Universidad de La Frontera, Francisco Salazar 01145, Temuco, Chile. ${ }^{3}$ Universidad de Santiago \\ de Compostela, Superior Technical School of Engineering, Rúa Lope Gómez de Marzoa s/n, \\ 15782 Santiago de Compostela, Spain. *Corresponding author: mrubilar@ufro.cl
}

\begin{abstract}
Flax (Linum usitatissimum) has been used for centuries as a source for oil extraction. In recent years it has attracted considerable interest as a result of studies which attribute potential health benefits to its components, including the prevention of chronic noncommunicable diseases. Among these compounds presenting biological activity, alphalinolenic acid, lignans and soluble fibre are of special interest. Southern Chile has comparative advantages for the cultivation of this crop. Together with its full processing, this crop could strengthen regional industry. The purpose of the present work is to learn how the best use can be made of these compounds, by studying flaxseed and flaxseed cake as sources of compounds of interest for food industry. Oil extracted from flaxseed contained $51.86 \%$ of linolenic, $16.34 \%$ of linoleic and $20.98 \%$ of oleic acid. Fractioning of defatted flaxseed cake produced a polyphenol content of $0.73 \mathrm{mg}$ GAE $\mathrm{g}^{-1}$ extract and a protein isolate of considerable purity, $53.15 \%$ yield with $0.78 \mathrm{~g}$ of albumin equivalent $\mathrm{g}^{-1}$ protein isolate. Additionally, a polysaccharide was isolated with low protein content as impurity, $10.71 \%$ yield with $1.37 \mathrm{mg}$ of glucose equivalent per gram of polysaccharide. This information will form the basis for assessing the extraction of products of interest for the food industry from flaxseed cake.
\end{abstract}

Keywords: flaxseed, flaxseed oil, protein, polysaccharide, polyphenols, food industry.

\section{INTRODUCTION}

Flax (Linum usitatissimum) is an annual species of the Linaceae family, growing to a height of $0.3-1 . \mathrm{m}$, which is cultivated for the production of textile fibre, seed and flaxseed (linseed) oil. Until a few years ago, flax was cultivated in Los Lagos Region, Southern Chile, mainly as raw material for textile industry. Today, flax is cultivated in Araucanía Region for oil extraction. Studies have shown that crop yield is higher in this Region, because of its soil and climate characteristics. Flax is best suited for fertile, fine textured, and loamy soils: An important factor is the amount of rainfall during the growing period. Adequate moisture and relatively cool temperatures, particularly during the period from flowering to maturity, seem to favour both oil content and oil quality.

The seed is located in the extremities of the branches in round capsules, each of which contains from one to ten seeds. It is well known that flax seeds are a source of high quality proteins, soluble fibre and a high content of polyunsaturated fatty 
acids (Pradhan et al., 2010). They present values of approximately $30-40 \%$ lipids, $20-25 \%$ proteins, $4-8 \%$ moisture, $3-4 \%$ ash (Coskuner and Karababa, 2007) and $20-25 \%$ dietary fibre, of which $10 \%$ corresponds to soluble fibre. This chemical composition varies with geographical location and variety.

In recent years flaxseed has become known as a functional food due to its nutritional composition, which has positive effects on disease prevention providing health-beneficial components such as alpha-linolenic acid (Bozan and Temelli, 2008), lignans and polysaccharides (other than starch). Due to their anti-hypercolesterolemic, anticarcinogenic and glucose metabolism controlling effects, these components may prevent or reduce the risk of various important diseases such as diabetes, lupus nephritis, arteriosclerosis and hormonedependent types of cancer (Bilek and Turhan, 2009, Williams et al., 2007). Likewise, antibacterial and fungistatic activity has been reported in oligosaccharides extracted from this seed (Guilloux et al., 2009), which can control the growth of pathogens affecting the agricultural sector, such as Alternia solani and Alternia alternata, as well as the human pathogen Candia albicans; it can also control the deterioration of foodstuffs by the fungi Penicillium chrysogenum, Fusarium graminearum and Aspergillus flavus (Xu et al., 2008).

Flaxseed oil, the principal component of this seed, is rich in alpha-linolenic, linoleic and oleic acids, and for years has been the focus of interest in this seed. After extraction of the oil (with a yield of approximately $30 \%$ ) a large quantity of pressed flaxseed cake remains, which is discarded and is still considered to be waste, or at best a sub-product of no value (Figuerola et al., 2008). The flaxseed cake is mainly used as a cattle feed, although flaxseed meal is used as an additive in baking products (Coskuner and Karababa, 2007).

Like many other seeds, flaxseed has high globulin content, $18.6 \%$, and contains a protein similar to albumin which accounts for $17.7 \%$ of total protein. Flaxseed protein is relatively rich in arginine, aspartic acid and glutamic acid, and the limiting aminoacids are lysine, methionine and cysteine (Chung et al., 2005). Flaxseed and flax products are among the richest sources of vegetable lignans, particularly the lignan secoisolariciresinol diglycoside (SDG). The health benefits of flaxseed lignans reside in their antioxidant capacity as sequestrators of hydroxyl radicals, and as estrogenic compounds due to their structural similarity to $17-\beta$-estradiol. The antioxidant capacity of flaxseed lignan (SDG) is related to the suppression of the oxidant conditions of the reactive species of oxygen. Secoisolariciresinol diglycoside and its aglycone secoisolariciresinol display a very high antioxidant capacity and act as protectors against damage to DNA and liposomes especially in the epithelial cells of the colon exposed to these compounds during the metabolism of colon bacteria which transform them into mammal lignans (Rajesha et al., 2006; Hu et al., 2007).

Another important component of flaxseed is Mucilage. This is obtained from aqueous extractions and its composition presents a heterogeneous mixture of polysaccharides made up of xylose, glucose, galactose, arabinose, ramnose, fucose and galacturonic acid (75\% neutral and 2 acid fractions). The neutral fraction is considered to consist of high molecular weight galacto -arabinoxylan $\left(\mathrm{Mw}=1.16 \times 10^{6} \mathrm{~h} \mathrm{~mol}^{-1}\right)$, while the 2 acid fractions are rhamnogalacturan in type $\left(6.5 \times 10^{5} \mathrm{~g} \mathrm{~mol}^{-1}\right.$ and $1.7 \times 10^{4} \mathrm{~g}$ $\mathrm{mol}^{-1}$ ) (Warrand et al., 2005; Guilloux et al., 2009). However, the molar mass of 
these fractions may differ according to the genotype and the climatic conditions under which the plant is grown (Goh et al., 2006). Some polysaccharides have ramified structures. Furthermore they often have high molecular weights, and tend to form aggregates in solution, which may mask the behaviour of the individual macro-molecules (Yang and Zhang, 2009). The range of polysaccharides which can be extracted from flaxseed has aroused great interest, not only for the obvious health benefits, principally due to the soluble fibre content, but also for the potential application of flaxseed in foods as a functional foodstuff, taking advantage of its physical properties as a thickener and emulsifier. The mucilage obtained from flaxseed cake is very similar to gum arabic in its emulsifying properties (Coskuner and Karababa, 2007) and is comparable to guar gum in its capacity to bind water.

One application sought for flaxseed polysaccharides is to substitute chemical additives for food conservation. Thus some oligosaccharides and polysaccharides have been described as food additives with antimicrobial properties, effective against pathogenous bacteria and fungi. A known group of oligosaccharides used for their antimicrobial effects are Chitooligosaccharides. Anti-tumour and antioxidant properties have also been described, and the capacity to capture free radicals. Another interesting feature of polysaccharides is that they encourage the growth and development of the gastrointestinal micro-flora, with a pro-biotic effect being described. For example, galacto-oligosaccharides, fructooligosaccharides and cyclodextrins are known to be pre-biotic substances.

Thus flaxseed and pressed flaxseed cake still have an immense usable potential in lipids, proteins, soluble fibre and lignans. The objective of the present work was to study flaxseed and pressed flaxseed cake as a resource of compounds which are of interest to the food industry, especially proteins, soluble fibre and polyphenol extract. A chemical and nutritional description was carried out using proximal analysis of flaxseed and flaxseed cake acquired in the $\mathrm{La}$ Araucanía Region, Chile. The fatty acid profile of the oil was assessed, as well as the contents of mucilage, protein and total polyphenols in the cake.

\section{MATERIALS AND METHODS}

\section{Raw material}

Flax seeds, a brown variety acquired in the local market in the La Araucanía Region, Chile, and flaxseed cake obtained as waste from cold pressing of flax seeds.

\section{Proximal analysis}

The chemical composition (content in moisture, lipids, nitrogen and ash) of the flaxseed cake was analysed according to the AOAC (1995) procedures.

\section{Oil extraction}

Flaxseed oil was obtained by pressing the seeds in a disc press and subsequent filtration (filter press).

\section{Identification of fatty acids}

The fatty acid composition was determined from the hydrolysis of 300 $\mathrm{mL}$ of flaxseed oil with a solution of $\mathrm{KOH}-\mathrm{MeOH}$ and boiling in a reflux condenser for $5 \mathrm{~min}$. The hydrolyzed sample was esterified by the addition of $\mathrm{HCl}-\mathrm{MeOH}$ and it was carried to a boil for $15 \mathrm{~min}$. After cooling, $12 \mathrm{~mL}$ of distilled water and $18 \mathrm{~mL}$ of $\mathrm{n}$-heptane were added to the mixture, then it was 
transferred to a funnel and after phase separation $10 \mathrm{~mL}$ of the ether solution were recovered. The solution was filtered through $\mathrm{Na}_{2} \mathrm{SO}_{4}$ and the solvent was evaporated by $\mathrm{N}_{2}$ stream. Finally, the sample was dissolved in $3 \mathrm{~mL}$ of chloroform and the fatty acid profile was analyzed in a Hewlett Packard gas chromatograph, model HP6890 GC System, equipped with a FID detector and a reversed phase capillary column SP2380 (30 m long, $0.25 \mathrm{~mm}$ internal diameter, $0.20 \mu \mathrm{m}$ film thickness), injector temperature: $250^{\circ} \mathrm{C}$, Split 1:100, injection volume $1 \mu \mathrm{L}$, using Helium as the transporter gas at a flow of 33 psi. The fatty acids were identified by reference to the Supelco-37 standard (for 37 fatty acids) and quantified using the HPCHEM Stations software, being expressed as a percentage of area, according to the total of the fatty acids identified.

\section{Defatting}

The flaxseed cake was defatted using Soxhlet extraction equipment with petroleum ether until the sample was exhausted.

Extraction of mucilage, polyphenols and protein

To extract the mucilage the defatted flax cake was mixed with distilled $\mathrm{H}_{2} \mathrm{O}$ (ratio 1:60) adjusting to $\mathrm{pH} 12$ with sodium hydroxide $1 \mathrm{~N}$. The mixture was stirred in a shaker at $200 \mathrm{rpm}$ for $30 \mathrm{~min}$ at $25^{\circ} \mathrm{C}$, and then centrifuged for $15 \mathrm{~min}$ at $4000 \mathrm{rpm}$. The supernatant was separated and the procedure was repeated twice more with the precipitate. The exhausted precipitate was used for the extraction of polyphenol compounds with aqueous ethanol at $50 \%$, solid-liquid ratio (1:60), in a shaker for $30 \mathrm{~min}$ at 200 $\mathrm{rpm}$ and $25^{\circ} \mathrm{C}$. The solution was centrifuged at $6500 \mathrm{rpm}$ for $15 \mathrm{~min}$ at $4^{\circ} \mathrm{C}$ and the supernatant containing the polyphenol extract (EPf) was concentrated in a rotary vacuum evaporating system at $60^{\circ} \mathrm{C}$.

To separate the protein, the supernatant was acidified to the

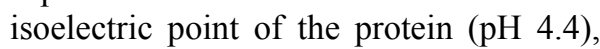
the neutralised protein was left to settle for $20 \mathrm{~min}$ to ensure the precipitation of the whole protein mass, then the protein isolate (APr) was centrifuged for $30 \mathrm{~min}$ at $6000 \mathrm{rpm}$ and $4^{\circ} \mathrm{C}$, and the precipitate was separated, frozen and lyophilized.

The supernatant containing the dissolved polysaccharide, which was purified with trichloroacetic acid for 12 hours at $4^{\circ} \mathrm{C}$ to precipitate the still dissolved proteins, was centrifuged for 30 min at $6000 \mathrm{rpm}$ at $4^{\circ} \mathrm{C}$. The supernatant was precipitated with an equal volume of ethanol for 12 hours at $-18^{\circ} \mathrm{C}$ (Cerning, 1990). The polymer was recovered by centrifuging at $7000 \mathrm{rpm}$ for $30 \mathrm{~min}$ at $4^{\circ} \mathrm{C}$. The pellet was dissolved in hot water and neutralizedwith $\mathrm{NaOH} 1 \mathrm{M}$.

The clear liquid obtained by centrifuging was dialysed for three days in water using a cut-off membrane of 6000 - $8000 \mathrm{Da}$ and changing the water twice daily. The dialysed solution was lyophilized to obtain the polysaccharide (Pol). The complete process diagram is shown in Figure 1.

Analysis of total sugars using the method of Dubois et al. (1958)

$400 \mu \mathrm{L}$ of phenol $\left(5 \% \mathrm{w} \mathrm{v}^{-1}\right)$ and $2 \mathrm{~mL}$ concentrated $\mathrm{H}_{2} \mathrm{SO}_{4}$ were added to 400 $\mu \mathrm{L}$ of a sample solution $\left(5 \mathrm{~g} \mathrm{~L}^{-1}\right)$. This was left to settle for $10 \mathrm{~min}$ at ambient temperature. It was shaken and kept at $27^{\circ} \mathrm{C}$ for $20 \mathrm{~min}$. The absorbance of the solution was read at $476 \mathrm{~nm}$.

Protein analysis using Bradford's method (1976)

$500 \mu \mathrm{L}$ of Comassie reagent and $1.2 \mathrm{~mL}$ of distilled water were added to $50 \mu \mathrm{L}$ of 


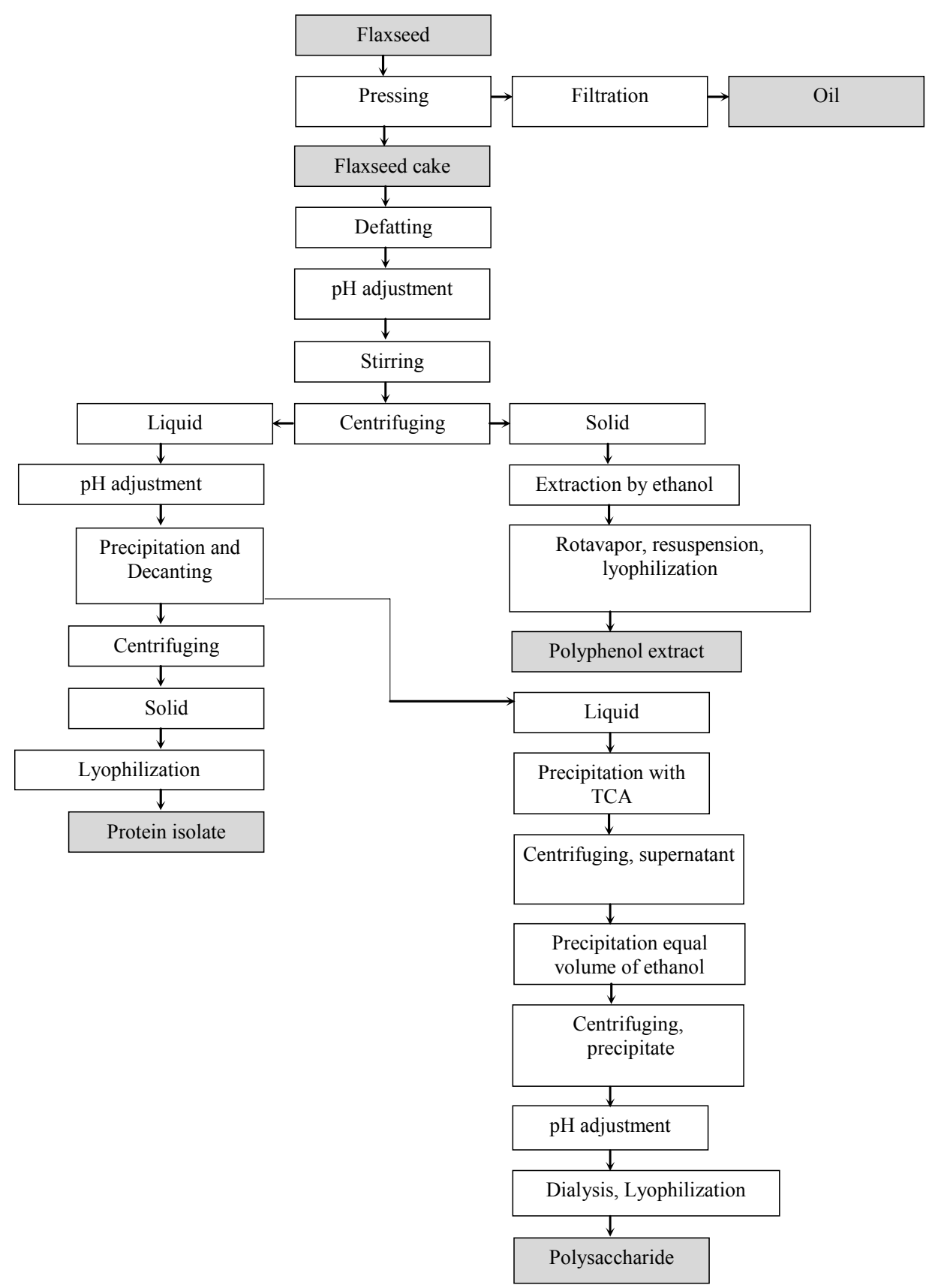

Figure 1. Obtaining polysaccharides, polyphenols and proteins from flaxseed cake. 
the sample. The absorbance was read at $595 \mathrm{~nm}$. The concentration of proteins in the solution was obtained by interpolation in the calibration curve:

$C\left(g L^{-1}\right)=0.9705$ Abs595-0.4875

\section{Determining the concentration polyphenol compound}

The total content of polyphenols was measured using the Folin-Ciocalteu method (Singleton and Rossi, 1965). A mixture of $2.5 \mathrm{ml}$ of Folin-Ciocalteu reagent, in 10 times dilution, $2.5 \mathrm{~mL}$ of a solution of sodium carbonate at $7.5 \%(\mathrm{w}$ $\mathrm{v}^{-1}$ ) and $0.5 \mathrm{~mL}$ of phenol extract was prepared. The mixture was kept at $45^{\circ} \mathrm{C}$ for $15 \mathrm{~min}$, and the absorbance was then measured at $765 \mathrm{~nm}$.

\section{RESULTS}

The chemical and nutritional composition of the flax seed presented a high content of oil and protein (43.90\% and $21.34 \%$ respectively) (Table 1). These proportions coincide with those reported by Mueller et al. (2010a): 45.2\% lipids and 23.4\% protein.

Table 1. Chemical composition of flaxseed

\begin{tabular}{lcc}
\hline Flaxseed & & Reference** $^{* *}$ \\
\hline Humidity & $8.30 \%$ & $7.4 \%$ \\
Protein* & $21.34 \%$ & $23.4 \%$ \\
Lipids & $43.90 \%$ & $45.2 \%$ \\
Fibre & $6.21 \%$ & -- \\
Ash & $2.66 \%$ & $3.5 \%$ \\
Non nitrogenated & 17.59 & $27.8 \%$ \\
extract & & \\
\hline
\end{tabular}

* Conversion factor used, 6.25

** Mueller et al., 2010a
For oil extraction, the values obtained by various authors reflect a wide range of extract yield, due principally to the different extraction processes used. However, many authors agree on the contents of linoleic acid (n-6) and alphalinolenic acid (n-3) found in flax oil: for n-3 a range between 50.0 and $57.0 \%$ is reported and for n-6 a range between 13.96 and $15 \%$ (Williams et al., 2007; Bozan and Temelli, 2008; Pradhan et al., 2010) of the total fatty acids extracted.

Furthermore, the content of oleic acid (n-9) coincides with the $21 \%$ found by Guillevic et al. (2009) and is close to the $15.07 \%$ reported by Bozan and Temelli (2008). The results of the fatty acids profile in flax oil are presented in Table 2. The used oil presented a free acidity of $1.3 \%$ oleic acid and a peroxide index of 0.17 meq $\mathrm{O}_{2} \mathrm{~kg}^{-1}$ of fat.

The flaxseed cake (prior to defatting) presented $21.78 \%$ of NNE, $29.37 \%$ lipids and $27.78 \%$ protein (Table 3 ). The protein value is close to the $29 \%$ reported by Goh et al. (2006) for pressed flaxseed cake. However, the composition differs from the values reported by Mueller et al., 2010a. In principle, the difference may be attributed to the low yield of flaxseed oil extracted in this study.

The results of the chemical composition of the flaxseed cake indicate that it may be expected to be an important source of protein isolate, polyphenols and soluble fibre. Prior to fractioning these compounds, a defatting process was applied to the cake to prevent the lipids becoming rancid.

Table 4 shows the results for protein yield $\mathrm{g}^{-1}$ defatted flaxseed cake and the content of proteins and impurities in the protein isolate. Table 5 shows the polysaccharide yield $\mathrm{g}^{-1}$ defatted flaxseed cake and the content of total sugars and impurities in the protein isolate. 
Table 2. Fatty acid profile for flaxseed oil

\begin{tabular}{|c|c|c|c|c|c|}
\hline Fatty acid & $\begin{array}{l}\text { \% methyl } \\
\text { ester }\end{array}$ & Fatty acid & $\begin{array}{l}\text { \% methyl } \\
\text { ester }\end{array}$ & Fatty acid & $\begin{array}{l}\text { \% methyl } \\
\text { ester }\end{array}$ \\
\hline $\begin{array}{l}\text { C4:0 } \\
\text { Butyric }\end{array}$ & ND & $\begin{array}{l}\mathrm{C} 18: 0 \\
\text { Stearic }\end{array}$ & 5.12 & $\begin{array}{l}\mathrm{C} 22: 1 \mathrm{E} \\
\text { rucic }\end{array}$ & ND \\
\hline $\begin{array}{l}\text { C6:0 } \\
\text { Caproic }\end{array}$ & ND & $\begin{array}{l}\text { C20:0 } \\
\text { Eicosanoic }\end{array}$ & ND & $\begin{array}{l}\text { C24:1 } \\
\text { Tetracosaenoic }\end{array}$ & ND \\
\hline $\begin{array}{l}\text { C8:0 } \\
\text { Caprylic }\end{array}$ & ND & $\begin{array}{l}\text { C22:0 } \\
\text { Docosanoic }\end{array}$ & ND & $\begin{array}{l}\text { C18:2 } \\
\text { Linoleic }\end{array}$ & 16.34 \\
\hline $\begin{array}{l}\text { C10:0 } \\
\text { Capric }\end{array}$ & ND & $\begin{array}{l}\text { C24:0 } \\
\text { Tetracosanoic }\end{array}$ & ND & $\begin{array}{l}\text { C18:3 } \\
\text { Linolenic }\end{array}$ & 51.86 \\
\hline $\begin{array}{l}\text { C11:0 } \\
\text { Undecanoic }\end{array}$ & ND & $\begin{array}{l}\text { C10:1 } \\
\text { Decaenoic }\end{array}$ & ND & $\begin{array}{l}\text { C20:2 } \\
\text { Eicosadienoic }\end{array}$ & ND \\
\hline $\begin{array}{l}\text { C12:0 } \\
\text { Lauric }\end{array}$ & ND & $\begin{array}{l}\text { C14:1 } \\
\text { Myristoleic }\end{array}$ & ND & $\begin{array}{l}\text { C20:3 } \\
\text { Eicosatrienoic }\end{array}$ & ND \\
\hline $\begin{array}{l}\text { C13:0 } \\
\text { Tridecanoic }\end{array}$ & ND & $\begin{array}{l}\text { C15:1 } \\
\text { Pentadecenoic }\end{array}$ & ND & $\begin{array}{l}\text { C20:4 } \\
\text { Eicosatetraenoic }\end{array}$ & ND \\
\hline $\begin{array}{l}\text { C14:0 } \\
\text { Myristic }\end{array}$ & 0.04 & $\begin{array}{l}\text { C16:1 } \\
\text { Palmitoleic }\end{array}$ & 0.05 & $\begin{array}{l}\text { C20:5 } \\
\text { Eicosapentaenoic }\end{array}$ & ND \\
\hline $\begin{array}{l}\text { C15:0 } \\
\text { Pentadecanoic }\end{array}$ & 0.01 & $\begin{array}{l}\text { C17:1 } \\
\text { Heptadecenoic }\end{array}$ & ND & $\begin{array}{l}\text { C22:2 } \\
\text { Docosadienoic }\end{array}$ & ND \\
\hline $\begin{array}{l}\text { C16:0 } \\
\text { Palmitic }\end{array}$ & 5.53 & $\begin{array}{l}\text { C18:1 } \\
\text { oleic }\end{array}$ & 20.98 & $\begin{array}{l}\text { C22:5 } \\
\text { Docosapentaenoic }\end{array}$ & ND \\
\hline $\begin{array}{l}\text { C17:0 } \\
\text { Heptadecanoic }\end{array}$ & 0.08 & $\begin{array}{l}\text { C20:1 } \\
\text { Eicoseanoic }\end{array}$ & ND & $\begin{array}{l}\text { C22:6 } \\
\text { Docosahexaenoic }\end{array}$ & ND \\
\hline
\end{tabular}

ND: Not determined

Table 3. Chemical composition of flaxseed cake

\begin{tabular}{lcc}
\hline Flaxseed cake & & Reference** $^{* *}$ \\
\hline Humidity & $10.65 \%$ & $9.7 \%$ \\
Protein* & $27.78 \%$ & $43.3 \%$ \\
Lipids & $29.37 \%$ & 1.67 \\
Fibre & $7.02 \%$ & -- \\
Ash & $3.40 \%$ & $6.4 \%$ \\
Non nitrogenated & $21.78 \%$ & $48.7 \%$ \\
extract & & \\
\hline
\end{tabular}

* Conversion factor used, 6.25

** Mueller et al., 2010a
Fractioning produced a protein and polysaccharide yield $\mathrm{g}^{-1}$ defatted flaxseed cake of $63.86 \%$ and all the soluble protein and insoluble fibre could be separated.

Mueller et al. (2010b) achieved a simplified extraction of soluble fibre:protein, which was $48 \%$ of the yield. The amount achieved in the present study shows a greater extraction of the separated compounds. The fact that the compounds could be obtained in isolation facilitates the subsequent study and evaluation of the physical and chemical properties of these products, which will be of use in determining possible applications. 
It is important to note that the protein isolate obtained is rich in proteins (Table 4), with 0.782 grams of albumin equivalent $\mathrm{g}^{-1}$ protein isolate and with a quantity of $0.027 \mathrm{mg}$ of glucose equivalent $\mathrm{g}^{-1}$ protein isolate, being polysaccharide, which has not been separated from the isolate (impurity) (Table 4). The polysaccharide isolate presents a sugar concentration of $1.37 \mathrm{mg}$ of glucose equivalent $\mathrm{g}^{-1}$ polysaccharide isolate, a value which is considered to be low, given that the used methodology represents the macro-molecules with the greatest weight as glucose. The of polysaccharide isolate presents $0.053 \mathrm{mg}$ albumin equivalent $\mathrm{g}^{-1}$ of polysaccharide isolate; this is protein which was not separated from the polysaccharide (impurity) (Table 5).

Of the polysaccharides extracted in the mucilage, Mueller et al. (2010a) tentatively identify the presence of glucose $36.5 \%$, followed by galactose and xylose $\quad(17.3$ and $17.2 \%$ respectively). Guilloux et al. (2009) reported that the sugars with the largest volumes are xylose $(21.7 \%)$, galactose $(8.1 \%)$, arabinose $(7.9 \%)$ and ramnose $(8.4 \%)$.

Table 4. Yield values of protein $\mathrm{g}^{-1}$ defatted flaxseed cake, protein content and impurities in protein isolate.

\begin{tabular}{|c|c|}
\hline Protein yield & $53.15 \pm 0.001 \% \mathrm{w} \mathrm{w}^{-1}$ \\
\hline Protein content & $0.782 \pm 0.113 \mathrm{~g}$ albumin equivalent $\mathrm{g}^{-1}$ protein isolate \\
\hline Impurities - sugars & $0.027 \mathrm{mg}$ glucose equivalent $\mathrm{g}^{-1}$ protein isolate \\
\hline
\end{tabular}

Table 5. Yield values of polysaccharide $\mathrm{g}^{-1}$ defatted flaxseed cake, total sugar content and impurities in polysaccharide isolated.

\begin{tabular}{ll}
\hline Polysaccharide yield & $10.71 \pm 0.006 \% \mathrm{w} \mathrm{w}^{-1}$ \\
Total sugar content & $1.37 \mathrm{mg}$ glucose equivalent $\mathrm{g}^{-1}$ polysaccharide \\
Protein impurity & $0.053 \pm 0.003 \mathrm{mg}^{-1}$ albumin equivalent $\mathrm{g}^{-1}$ polysaccharide \\
\hline
\end{tabular}

Finally, the polyphenol extract obtained using aqueous ethanol at $50 \%$ presented $0.7275 \pm 0.0022 \mathrm{mg} \mathrm{GAE} \mathrm{g}^{-1}$ extract. This value is low when compared to the 20.8 mg GAE g ${ }^{-1}$ flaxseed cake extract (Ho et al., 2007), considering that extraction with aqueous ethanol at $50 \%$ showed a greater yield in polyphenol extraction (Shene et al., 2009). However the activity of the polyphenol compounds in flaxseed has been extensively studied for example flaxseed polyphenols in their pure form control nephritis lupica in humans. Flaxseed lignans combined with isoflavones and insulin are administered as a drink to treat menopause symptoms in women, while biscuits made of flaxseed lignans combined with genistein have proved useful in combating cancer (Oomah, 2001) showing the importance of these compounds for human health. 


\section{CONCLUSIONS}

The oil extracted from flaxseed is rich in linolenic, linoleic and oleic acids. Fractioning of the defatted flaxseed cake produced a polyphenol extract, a protein isolate of considerable purity, and a polysaccharide isolate with a low content of protein as an impurity. The information collected will serve as a basis for studies which will be of interest for food industry.

\section{ACKNOWLEDGEMENTS}

The authors are grateful for financing from Fondecyt Project 1090516 and projects of the Research Directorate of UFRO, Performance Agreement I and II 2009; and to GAP technical support staff.

\section{REFERENCES}

A.O.A.C., 1995. Official methods of analysis $\left(16^{\text {th }}\right.$ Ed.). Arlington, VA: Association of Analytical Chemists, $1094 \mathrm{p}$.

Bilek, E., Turhan, S. 2009. Enhancement of the nutritional status of beef patties by adding flaxseed flour. Meat Sci. 82, 472-477.

Bozan, B., Temelli, F. 2008. Chemical composition and oxidative stability of flax, safflower and poppy seed and seed oils. Bioresource Technol. 99, 6354-6359.

Bradford, M. 1976. A rapid and Sensitive Method for the Quantitation of Microgram Quantities of Protein Utilizing the Principle of Protein-Dye Binding. Anal Biochem.72, 248-254.

Coskuner, Y., Karababa E. 2007. Some physical properties of flaxseed (Linum usitatissimum L.). J. Food Eng. 78, 1067-1073.

Chung, M., Lei, B., Li-Chan, E. 2005. Isolation and structural characterization of the major protein fraction from NorMan flaxseed (Linum usitatissimum L.). Food Chem. 90, 271279.
Dubois, M., Gilles, K.A., Hamilton, J.K., Smith, F. 1956. Colorimetric method for determination of sugars and related substances. Anal. Chem. 28, 350-356.

Figuerola, F., Muñoz, O., Estévez, A. 2008. La linaza como fuente de compuestos bioactivos para la elaboración de alimentos. AgroSur 36, 4958.

Goh, K., Pinder, D., Hall, C., Hemar, Y. 2006. Rheological and light scattering properties of flaxseed polysaccharide aqueous solutions. Biomacromolecules 7, 3098-3103.

Guillevic, M., Kouba, M., Mourot, J. 2009 Effect of a linseed diet or a sunflower diet on performances, fatty acid composition, lipogenic enzyme activities and stearoyl-CoA-desaturase activity in the pig. Livest. Sci., 124, 288-294.

Guilloux, K., Gaillard, I., Courtois, J., Courtois, B., Petit, E. 2009. Production of Arabinoxylan-oligosaccharides from Flaxseed (Linum usitatissimum). J. Agr. Food Chem. 57, 11308-11313.

Ho, C., Cacace, J., Mazza, G. 2007. Extraction of lignans, proteins and carbohydrates from flaxseed meal with pressurized low polarity water. LWT- Food Sci. Technol. 40, 1637-1647.

Hu, C., Yuan, V., Kitts, D. 2007. Antioxidant activities of the flaxseed lignan secoisolariciresinol diglucoside, its aglycone secoisolariciresinol and the mammalan lignans enterodiol and enterolactone in vitro. Food Chem. Toxicol. 45, 2219-2227

Mueller, K., Eisner, P., Yoshie-Stark, Y., Nakada, R., Kirchhoff, E. 2010a. Functional properties and chemical composition of fractionated brown and yellow linseed meal (Linum usitatissimum), J. Food Eng. 98, 453-460

Mueller, K., Eisner, P., Kirchhoff, E. 2010b. Simplified fractionation process for linseed meal by alkaline extraction - Functional properties of protein and fibre fractions. J. Food Eng. 99, 4954

Oomah, B. 2001. Flaxseed as a functional food source. J. Sci. Food Agr. 81, 889-894.

Peschel, W., Dieckmann, W., Sonnenschein, M., Plescher, A. 2007. High antioxidant potential of pressing residues from evening primrose in comparison to other oilseed cakes and plant antioxidants. Ind. Crop Prod. 25, 44 54. 
Pradhan, R., Meda, V., Rout, P., Naik, S. 2010. Supercritical $\mathrm{CO}_{2}$ extraction of fatty oil from flaxseed and comparison with screw press expression and solvent extraction processes. J. Food Eng. 98, 393-397

Rajesha, J., Murthy, K., Kumar, M., Madhusudhan, B., Ravishankar, G. 2006. Antioxidant potentials of flaxseed in vivo model. J. Agr. Food Chem. 54, 3794-3799.

Shene, C., Reyes, A., Villarroel, M., Sineiro, J., Pinelo, M., Rubilar, M. 2009. Plant location and extraction procedure strongly alter the antimicrobial activity of murta extracts. Eur. Food Res. Tech. 228(3), 467-475.

Singleton, V.L., Rossi, J.A. 1965. Colorimetry of total phenolics with phosphormolybdicphosphotungstic acid reagents. Am. J. Enol. Viticult. 16, 144-158.

Warrand, J., Michaud, P., Picton, L., Muller, G., Courtis, B., Ralainirina, R., Courtis, J. 2005. Flax (Linum usitatissimum) Seed Cake: A Potential Source of High Molecular Weight Arabinoxylans? J. Agr. Food Chem. 53, 1449 1452.
Williams, D., Verghese, M., Walker, L., Boateng, J., Shackelford, L., Chawan, C. 2007. Flax seed oil and flax seed meal reduce the formation of aberrant crypt foci (ACF) in azoxymethane-induced colon cancer in Fisher 344 male rats. Food Chem. Toxicol. 45, 153-159.

Xu, Y., Hall, C., Wolf-Hall, C. 2008. Antifungal activity stability of flaxseed protein extract using response surface methodology. J. Food Sci. 73, 914.

Yang, L., Zhang, L. 2009. Chemical structural and chain conformational characterization of some bioactive polysaccharides isolated from natural sources. Carbohyd. Polym. 76, 349-361. 